\title{
COREFSPONDENOE.
}

\section{OFFASTER PILULA.}

Sin,-Mr. Sherborn is right as to the unfortunate slip in the recently published Memoir on the Geology of Southampton. Having Dr. Barrois' book open before me when I wrote the paragraph, I seem to have forgotten for the moment the more recent authorities. Elsewhere I have correctly referred the highest Chalk in that zeighbourhood to the zone of Actinocamax quadratus.

October 8th, 1902.

Clement Reid.

\section{LAKES OF SNOWDONIA.}

SIR,-In my letter which appeared in the September number of your Magazine (p. 430, line 16 from top of letter) is an erratum which destroys the significance of the sentence. For 'sunny' read 'snowy.' J. E. Mark.

Cambridge, October $9 t h, 1902$.

\section{RIVER DEVELOPMENT.}

Sik,-Because I frankly admitted that statements in my paper in Natural Science, vol. xiv, 1899, might be termed " mere speculation," giving as the reason that the maps which we can obtain do not supply sufficient information for the precise study required, Mr. Strahan thinks he was justified in characterizing my work as "transgressing the limits of legitimate speculation." Yet he had just admitted not having seen the paper in Natural Science when he made that remark.

There is all the difference between my admission and Mr. Strahan's remark. Any theory is a speculation. I gave the grounds on which the theory was based; and I followed out the logical conclusions. The basis of the theory is that the original rivers flowed with the dip. As the general dip of the area in question is from north-west to south-east, that involves an original river-system such as was depicted in my map. Strong evidence in favour of the theory is found in the peculiar course of the tributaries on the left bank of the Severn, and in the breaches of the Cotteswold escarpment.

It is difficult to admit that in a country of simple structure such as the Cotteswolds, a Chalk anticline and all that it involves could be masked.

As to the indefinite westerly rise of the Chalk, is it so very great? The rise of the Oolitic surface on which the Chalk could have rested is about 800 feet in 25 miles. Having regard to the thickness of the Chalk and the extent of its outcrop, can its rise be much more than this?

One word about the Moreton anticline. I described an anticline there, formed and covered over again in Inferior Oolite time. We 